\title{
PENGARUH METODE LATIHAN DAN MOTIVASI BEROLAHRAGA TERHADAP PENINGKATAN DAYA TAHAN TUBUH PADA MEMBER CELEBRITY FITNESS
}

\author{
Milda Vinna Br Payung ${ }^{1}$, Joen Parningotan Purba ${ }^{2}$ \\ Universitas Negeri Jakarta \\ joenpoerba@gmail.com
}

\begin{abstract}
Abstrak
Penelitian ini bertujuan untuk mengetahui pengaruh metode latihan dan motivasi berolahraga terhadap peningkatan daya tahan MemberCelebrity Fitness. Di samping itu, penelitian juga bertujuan untuk mengetahui pengaruh motivasi terhadap kedua gaya mengajar tersebut. Gaya mengajar dalam penelitian ini adalah gaya mengajar metode latihan.

Penelitian dilaksanakan di Celebrity fitnessla piazza tahun 2019. Metode penelitian adalah eksperimen dengan rancangan treatment by level $2 \times 2$ dengan jumlah sampel sebanyak 40 orang.

Hasil penelitian ini adalah sebagai berikut: (1) secara keseluruhan terdapat perbedaan antara metode latihan circuit training dengan senam erobic mix impact terhadap peningkatan daya tahan; (2) bagi siswa yang memiliki mtoivasi berolahraga tinggi, pemberian metode latihan circuit training memberikan pengaruh yang lebih baik dibandingkan dengan metode latihan senam aerobic mix impact(3) bagi member yang memiliki motivasi rendah, metode latihan senam aerobic mix impact memberikan pengaruh yang lebih baik dibandingkan dengan metode latihan circuit training. dan (4) terdapat interaksi antara metode latihan senam aerobic mix impact dengan peningkatan daya tahan tubuh.
\end{abstract}

Kata Kunci : Pengaruh Metode Latihan, Motivasi berolahraga,dalam Peningkatan daya tahan

\begin{abstract}
This study aims to determine the effect of exercise training methods and motivation to increase durability Members Celebrity Fitness. In addition, penelitian also aims to determine the effect of motivation on both the teaching style. This style of teaching in this study is the teaching style training methods.

Research conducted at the Celebrity fitness la piazza 2019. The research method is experimental design with treatment by a $2 \times 2$ level with a sample size of 40 people.

Results of this study are as follows: (1) overall there is a difference between the method of circuit training workout with gymnastic erobic mix impact on increased durability; (2) for students who have high exercise mtoivasi, giving circuit training exercise method gives a better effect than the method mix impact aerobic exercises (3) for members who have low motivation, method mix impact aerobic exercises give better effect compared with the method of circuit training workout. and (4) there is interaction between the method mix impact aerobic exercises to increase endurance.
\end{abstract}

Key Words: Effects of Exercise Method, motivation to exercise, in improving endurance

Dipublikasikan Oleh :

UPT Publikasi dan Pengelolaan Jurnal

Universitas Islam Kalimantan Muhammad Arsyad Al-Banjari Banjarmasin 


\section{PENDAHULUAN}

Perkembangan dan kemajuan padaera globalisi sekarang ini dimana ilmu pengetahuan dan teknologi berkembang semakin cepat dan pesat adalah salah satu moderenisasi. Ditandai dengan banyak ditemukannya penemuan-penemuan baru dalam bidang ilmu pengetahuan dan teknologi yang semakin canggih. Contohnya peralatan-peralatan seperti pesawat terbang, mobil, smart phone dan lain sebagainya. Serta dalam bidang makanan ditemukannya beberapa penemuan bahan makanan baru seperti hasil permentasi susu menjadi keju, ragi sebagai pengembang roti dan masih banyak lagi yang lainnya. Perkembangan ini membawa juga dampak pada pola hidup dan prilaku masyarakat yang menjadi serba modern baik dari lapisan masyarakat bawah, masyarakat menengah dan sudah pasti masyarakat yang perekonomiannya lebih dari cukup. Perkembangan dan prilaku masyarakat yang seperti itu memberikan banyak sekali dampak positif dan negatif terhadap kehidupan manusia itu sendiri, salah satu dampak nyata yang terlihat adalah memberikan banyak kemudahan dalam melakukan aktivitas sehari hari untuk memenuhi kebutuhan hidup dengan waktu yang lebih cepat dan efektif. Namun sebaliknya dengan perkembangan dan prilaku masyarakat yang sangat modern ini membuat masyarakat tidak banyak melakukan aktivitas fisik yang manfaatnya besar bagi kesehatan mereka sendiri.

Di kota-kota besar dimana masyarakat sibuk dengan aktivitas dan kegiatannya baik itu di kantor, sekolah, kampus dan bahkan di rumah yang memakan banyak waktu dan disibukan dengan kegiatannya masing-masing sehingga tidak ada waktu senggang untuk melakukan aktivitas olahraga. Selain itu makin sempit karena termakannya lahan untuk pembangunan mengakibatkan manusia tidak memiliki sarana dan prasarana olahraga yang baik, sehingga masyarakat tidak dapat melakukan aktivitas fisik mengakibatkan timbulnya berbagai macam penyakit karena kurang gerak.

Masyarakat di era modern juga sering mengalami tekanan psikis yang sering berpengaruh bagi kehidupannya. Keadaan serta tuntutan di tempat mereka melakukan aktivitas seperti kantor, sekolah, kampus bahkan rumah sering memberikan ketegangan dan tekanan. Masalah mengenai target dan tuntutan hidup, persaingan dalam dunia kerja, keamanan, kenyamanan serta kebutuhan hidup mereka memberikan tekanan yang mempengaruhi psikis mereka. Keadaan ini juga makin bertambah buruk jika masyarakat modern yang penuh dengan aktivitas kerja dan ditunjang dengan peralatan yang serba canggih yang menyebabkan berkurangnya aktifitas fisik mereka melakukan pola makan yang tidak teratur dan mengkonsumsi gizi yang kurang seimbang.

Selama ini masyarakat justru memperparah pola hidup dan prilaku modern mereka dengan mengkonsumsi makanan yang tidak sehat.

Mereka kurang menyadari akan pola makan yang baik dan sehat. Selama ini masyarakat hanya mengetahui apa yang sering mereka dengar yaitu tentang empat sehat lima sempurna saja. Sementara mereka tidak mengetahui komposisi untuk memenuhi tentang empat sehat lima sempurna tersebut. Banyaknya makanan-makanan cepat saji juga memperparah pola makan pada masyarakat modern. Dengan waktu kerja dan aktivitas yang padat masyarakat cenderung lebih sering mengkonsumsi makanan cepat saji. Sehingga terjadi ketidakseimbangan antara apa yang mereka konsumsi dan apa yang mereka keluarkan. Dalam hal ini timbul penyakit seperti obessitas, kanker, dan penyakit-penyakit lainnya yang berdampak buruk bagi kesehatan bahkan bisa menyebabkan kematian.

Menjaga kesehatan dengan melakukan pola hidup sehat sangatlah penting, karena dengan aktivitas yang padat manusia dituntut mampu memiliki akan ketahanan tubuh yang baik. Hal tersebut bisa kita dapat dengan beberapa faktor seperti : (1) berolahraga, (2) istirahat yang cukup dan (3) menjaga pola makan yang baik. Berolahraga adalah salah satu faktor penting untuk menjaga kebugaran jasmani seseorang. Karena berolahraga bukan hanya untuk pencapaian prestasi melainkan hal yang paling utama didapat dengan berolahraga adalah kesehatan. Hakikat olahraga adalah proses aktivitas fisik untuk meningkatkan kualitas individu, baik secara fisik, mental, maupun emosional.

Dipublikasikan Oleh : 
Olahraga sebagai media pencapaian kebugaran jasmani tentu saja dalam pelaksanaannya hal-hal mengenai olahraga itu sendiri, porsi dalam berolahraga, serta perubahan fungsi organ tubuh sebagai akibat dari aktivitas olahraga tersebut. Banyak manfaat yang didapat dengan olahraga secara teratur, diantaranya : (1) memperluas pergerakan persendian, (2) kekuatan dan daya tahan meningkat, (3) mengaktifkan produksi sel darah merah dalam sumsum tulang belakang, dan masih banyak lagi manfaat yang didapat dengan berolahraga secara teratur.

\section{Deskripsi Konseptual}

Seseorang dikatakan mempunyai daya tahan yang baik apabila ia tidak mudah lelah atau dapat terus bergerak dalam keadaan kelelahan atau ia mampu bekerja tanpa mengalami kelelahan yang berlebihan setelah menyelesaikan pekerjaannya tersebut. Kualitas daya tahan paru jantungdinyatakan dengan VO2 Max, yakni banyaknya oksigen maksimum yang dapat dikonsumsi dalam satuan Ml/kg BB/Menit.Daya tahan adalah faktor yang sangat penting dalam kesehatan, bagaimana dengan memiliki daya tahan tubuh yang terjaga individu bisa melakukan aktivitas-aktivitas kerja dengan sangat baik. Semua individu perlu memiliki daya tahan yang baik untuk menunjang aktivitas kerja mereka termasuk membercelebrity fitness.Berdasarkan hasil observasi yang saya temukan selama memberikan pelatihan pada program IMT (Indeks Massa Tubuh) pada membercelebrity fitness masih banyak terlihat para anggota yang tidak memiliki ketahanan tubuh yang baik. Data ini diperoleh berdasarkan survey peneliti tentang daya tahan tubuh para membercelebrity fitness khususnya para wanita. Banyak hal yang mempengaruhi salah satunya dengan aktivitas kerja yang padat dan minimnya aktivitas gerak kurang mempunyai banyak waktu dan motivasi untuk melakukan kegiatan olahraga. Ditambah lagi dengan pola hidup sehat yang belum disadari oleh tiap member tersebut.

\section{Hasil Latihan}

Sebuah program pelatihan akan membuahkan hasil yang baik bila disusun berdasarkan atas pengembangan kemampuan fisiologis khusus yang dibutuhkan dalam penampilan suatu cabang olahraga dengan takaran yang tepat. Dalam pengertian sehari-hari, takaran berarti ukuran isi atau alat untuk mengukur.

Sebelum menentukan takaran pelatihan, terlebih dahulu harus dilakukan tes (pretest).Tujuannya agar dapat diketahui secara tepat kemampuan awal dari calon atlet.Berdasarkan data kemampuan awal inilah takaran pelatihan ditentukan.Dengan demikian takaran awal yang diberikan dapat tepat mengacu pada kemampuan sebenarnya dari calon atlet bersangkutan."Secara umum takaran suatu pelatihan mengandung tiga unsur pokok yaitu intensitas, volume, dan densitas.

\section{Circuit Training}

Isi dari latihan sirkuit latihannya bisa berupa naik turun tangga, lari ke samping belakang, melempar bola, memukulkan raket, melompat lompat, mengangkat beban, dan sebagainya. Setiap bentuk latihan harus dipilih sesuai dengan otot-otot atau unsur apa saja yang kita ingin kembangkan. Dalam satu sirkuit biasanya terdiri dari beberapa post/unit latihan (tidak terlalu banyak atau sedikit).

\section{Senam Aerobic Mix Impact}

Senam aeerobik membutuhkan gerakan gerakan seperti menendang, melompat, berbaris, naik tangga dan menggerakan twist adalah contoh-contoh berbagai macam gerakan yang berbeda dimana kaki anda menjejak lantai dalam cara yang berbeda. Senam aerobik ini dibagi menjadi 3 model latihan senam aerobik, antara lain:

1. Senam Aerobik Low impact,

2. Senam Aerobik Mix Impact,

Dipublikasikan Oleh : 


\section{Senam Aerobik High Impact.}

Senam aerobik mix impact sangat cocok dilakukan untuk meningkatkan kebugaran, menurunkan berat badan dan mengurangi lemak pada tubuh. Karena pembebanan yang dilakukan pada senam aerobik mix impact sangat cocok dengan kriteria-kriteria latihan tersebut.

\section{Metode Latihan Circuit Training}

Metode sirkuit biasanya terdiri dari beberapa item (macam) latihan yang harus dilakukan dalam waktu tertentu. Setelah selesai pada satu item latihan segera pindah pada item yang lain tanpa waktu recovery dan interval, demikian seterusnya sampai selutuh item latihan selesai dilakukan, sehingga disebut telah melakukan satu sirkuit.Satu sirkuit latihan dikatakan selesai, bila seorang atlet telah menyelesaikan latihan di semua stasiun sesuai dengan dosis yang telah ditetapkan. Istilah cirkuit training dalam bahasaIndonesia adalah latihan sirkuit. Latihan sirkuit adalah latihan yang dilakukan dalam satu putaran dan selama satu putaran itu terdapat beberapa pos. Pada setiap pos itu atlet melakukan tugas, dalam latihan sirkuit dapat diberikan variasi latihan.

\section{Metode Latihan Senam Aerobic Mix Impact}

Senam aerobik mix impact adalah latihan gabungan dari high impact dan low impact. Yaitu pada gerakan-gerakan dimana tumit mengangkat tetapi jari kaki tetap berada dilantai. Adapun sistematika dalam penyajian senam aerobik mix impact adalah sebagai berikut

Dalam latihan inti satu terdiri dari tiga macam yaitu :

1. Pre aerobik, pada fase awal inti satu, durasi latihan kurang lebih 5 menitdengan intensitas cukup. Tujuannya adalah meningkatkan intensitas kerja tubuh.

2. Peak aerobik, kemudian latihan dilanjutkan dengan intensitas yang lebih beratberlangsung kurang lebih selama 15 menit. Durasi disesuaikan dengan kemampuan fisik para perserta.Tujuannya adalah memaksimalkan intensitas kerja tubuh, kondisiyang lebih tinggi dari kondisi awal tubuh.

3. Post aerobik, setelah berkerja maka pada tahapan ini intensitas diturunkan perlahan-lahan, durasinya selesai dengan durasi kurang lebih selama 5 menit. Tujuannya adalah menurunkan intensitas kerjatubuh secara bertahap hingga mencapai kondisi awal tubuh.

\section{Motivasi Latihan}

Secara umum, istilah motivasi mengacu kepada faktor-faktor dan proses-proses yang dimaksud untuk mendorong orang untuk beraksi atau untuk tidak beraksi dalam berbagai situasi.Motivasi berasal dari kata bahasa Latin "movere" yang artinya bergerak.Sebelum mengacu pada pengertian motivasi, terlebih dahulu kita menelaah pengidentifikasian kata motif dan motivasi. Motif adalah daya penggerak dalam diri seseorang untuk melakukan aktivitas tertentu, demi mencapai tujuan tertentu. Dengan demikian, motivasi merupakan dorongan yang terdapat dalam diri seseorang untuk berusaha mengadakan perubahan tingkah laku yang lebih baik dalam memenuhi kebutuhannya.

\section{METODE}

Penelitian ini bertujuan untuk memperoleh gambaran tentang perbedaan variabel bebas terhadap variabel terikat. Terdapatduavariabel bebas dalampenelitianini, yaitu peningkatan daya tahan tubuh dan motivasi berolahraga. Sebagaivariabelterikatadalahlatihandalam peningkatan daya tahan member celebrity fitness.

Penelitian ini telah dilaksanakan di celebrity fitness la piazzaJakartaJalan Boulevard, dilakukan pada bulan april tahun 2019. Pelaksanaan penelitian yaitu direncanakan dimulai bulan Januari digunakan untuk persiapan, penentuan sampel penelitian dan tes pendahuluan untuk mengumpulkan data tentang kecerdasan emosi dari sampel yang dipergunakan. Selanjutnya data awal tersebut dipergunakan untuk menentukan kelompok motivasi tinggi dan motivasi rendah.

Dipublikasikan Oleh : 
Metode yang digunakan dalam penelitian ini adalah metode eksperimen dengan desain Treatment by Level $2 \times 2$. Penentuan desain merujuk pada pendapat Sudjana, yaitu unit-unit eksperimen dikelompokan dalam sel sedemikian rupa sehingga unit-unit eksperimen di dalam sel relatif homogen dan banyak unit eksperimen di dalam sel sama dengan banyak perlakuan yang sedang diteliti. Perlakuan dilakukan secara acak kepada unit-unit eksperimen didalam setiap sel

Untuk menganalisa data di dalam penelitian ini digunakan teknik analisis varians (anava) dua jalur dengan desain Treatment By Level $2 \times 2$ pada taraf signifikan $\alpha=0,05$. Sebelum melakukan analisa varian, sebagai syarat memenuhi persyaratan analisis data terlebih dahulu dilakukan uji normalitas sampel dengan Liliefors, sedangkan untuk mencari tingkat homogenitas varians populasi dengan menggunkan uji Barlett. Selanjutnya, jika terdapat interaksi (hasil dari perhitungan anava) dilanjutkan dengan uji Tukey yang bertujuan untuk mengetahui tingkat signifikansi F hitung dengan taraf signifikansi $\alpha=0,05$.

\section{HASIL PEMBAHASAN}

Pada bagian Bab IV ini dikemukakan hasil-hasil penelitian yang telah diperoleh berdasarkan hasil analisis deskriptif dan analisis inferensial.Analisis deskriptif dimaksudkan untuk menggambarkan secara umum karakteristik variabel penelitian dalam bentuk skor rata-rata, skor median, skor modus, standar deviasi dan varians.Analisis inferensial digunakan untuk pengujian hipotesis penelitian. Uji persyaratan analisis terdiri dari uji normalitas data dan uji homogenitas data, sedangkan pengujian hipotesis penelitian terdiri dari uji metode berolahraga terhadap peningkatan daya tahan dengan mempertimbangkan motivasi latihan serta interaksi antara kedua faktor tersebut. Selain itu, ditampilkan hasil-hasil data penunjang dalam bentuk uji perbandingan antara kedua kelompok.Selanjutnya dalam bab ini dikemukakan pembahasan dan keterbatasan dari hasil penelitian yang diperoleh.

\section{KESIMPULAN}

Berdasarkan hasil analisis data, hasil pengujian hipotesis dan hasil pembahasan penelitian yang telah diperoleh maka dapat dijelaskan beberapa kesimpulan, implikasi penelitian dan saran sebagai berikut:

1. Secara keseluruhan terdapat perbedaan antara metode latihan circuit training dan senam aerobic mix impact terhadap peningkatan daya tahan tubuh pada member celebrity fitness.

2. Terdapat interaksi antara metode latihan circuit training dan senam aerobic mix impact terhadap peningkatan daya tahan tubuh pada member celebrity fitness.

3. Bagi member yang memiliki motivasi berolahraga tinggi, pemberianmetode latihan circuit training memberikan pengaruh yang lebih baik dibandingkan senam aerobic mix impact terhadap peningkatan daya tahan tubuh pada member celebrity fitness.

4. Bagi member yang memiliki motivasi berolahraga rendah, pemberian metode latihan senam aerobic mix impactmemberikan pengaruh yang lebih baik dibandingkan dengan metode latihan circuit training.

\section{Saran}

Dari temuan ini mengindikasikan bahwa motivasi berolahraga perlu dipertimbangkan dalam peningkatan hasil daya tahan pada member celebrity fitness. Perlu diketahui bahwa peningkatan daya tahan tubuhmembutuhkan motivasi berolahraga yang tinggi dalam meningkatkan daya tahan tersebut, sehingga mempermudah dalam pencapaian hasil daya tahan, dengan demikian motivasi berolahraga tersebut merupakan suatu penunjang yang sangat dibutuhkan dalam meningkatkan daya tahan. Dengan kata lain bahwa untuk meningkatkan daya tahan tubuh perlu melibatkan faktor motivasi berolahraga.

Temuan lain dalam penelitian ini, bahwa dari data yang diperoleh menunjukan secara keseluruhanmetode latihan circuit training memberikan pengaruh yang lebih baik dibandingkan dengan

Dipublikasikan Oleh : 
metode latiha senam aerobic mix impact terhadap peningkatan daya tahan tubuh. Dengan demikian, dapat direkomendasikan bahwa metode latihan circuit training dapat diterapkan dalam meningkatkan daya tahan tubuh member celebrity fitness.

Bagi member yang memiliki motivasi berolahraga tinggi, data yang diperoleh menunjukan bahwametode latihan circuit training memberikan pengaruh yang lebih baik dibandingkan dengan metode latihan senam aerobic mix impact terhadap peningkatan daya tahan tubuh.Dengan demikian, dapat direkomendasikan metode latihan circuit training lebih cocok diterapkan bagi member yang memiliki motivasi berolahraga tinggi dalam meningkatkan daya tahan tubuh.

Bagi member yang memiliki motivasi berolahraga rendah, data yang diperoleh menunjukan bahwa metode latihan senam aerobic mix impact memberikan pengaruh yang lebih baik dibandingkan dengan metode latihan circuit training terhadap Peningkatan daya tahan tubuh. Dengan demikian, dapat direkomendasikan metode latihan senam aerobic mix impact diterapkan bagi member yang memiliki motivasiberolahragarendah dalam meningkatkan daya tahan tubuh.

\section{REFERENSI}

Anne L. Rothstein L., Research Desain\&Satisfictics for Physical Education, New Jersey: Prentice Hall, Inc., 2015

Brian J. Sharkey, KebugarandanKesehatan, Jakarta: PT. RajagrafindoPersada, 2014.

Djaali, Psikoloi Pendidikan, Jakarta: Bumi Aksara, 2013

FahmyFachrezzy, MateripenataranInstrukturAerobik, Jakarta: 2014

James Tangkudung, Sportmed, M.PddanWahyuningtyasPuspitarini, S.Pd, M.Kes, KepelatihanOlahraga "PembinaanPrestasiOlahraga" EdisiII, Jakarta: Cerdas Jaya, 2013.

JohansyahLubis, M.Pd, PanduanPraktisPenyusunan Program Latihan, Jakarta: Raja GrafindoPersada, 2013

Lynne Brick. Bugar dengan Senam Aerobik. Terjemahan Anna Agustina (Jakarta P.T. Raja Grafindo Persada, 2014),

Lynne Brick. Bugar dengan Senam Aerobik. Terjemahan Anna Agustina (Jakarta P.T. Raja Grafindo Persada, 2015),

Mahfan, KamusLengkapBahasa \&Sastra Indonesia, Jakarta: Sandro Jaya

RoesdiyantodanBudiwanto, Dasar-DasarKepelatihanOlahraga, Malang: 2013

Sukadiyanto dan Muluk, Pengantar Teori dan Metodologi Melatih Fisik, Bandung: Lubuk Agung,h.

Dipublikasikan Oleh :

UPT Publikasi dan Pengelolaan Jurnal

Universitas Islam Kalimantan Muhammad Arsyad Al-Banjari Banjarmasin 